\title{
Research on Auxiliary Teaching Mode Based on We-chat Public Platform Yantao Wang ${ }^{\mathrm{a}}$, Zhu Li ${ }^{\mathrm{b}}$

\author{
School of Economics and Management, Northeast Dianli University, Jilin 132012, China \\ awangyantao@gmail.com, b948767575@qq.com
}

Keywords: Auxiliary teaching; Teaching mode; Mobile Internet; Online learning; We-chat public platform.

\begin{abstract}
An auxiliary teaching mode based on mobile Internet technology is proposed. After the analysis of the characteristics, aims, teaching process, learning needs and current hot spots of higher education teaching, this paper puts forward the structure, framework, process and implementation method of mobile auxiliary teaching mode based on the we-chat public platform. Through the analysis, several important conclusions were obtained. Nowadays, the mobile Internet has been basically popularized, it is important to the auxiliary teaching which must have clear objectives, timely interaction and rich in content, to meet the needs of higher education. The practical application proves that the auxiliary teaching mode based on we-chat public platform is in line with the characteristics of the times. It is a useful supplement to the classroom teaching.
\end{abstract}

\section{Introduction}

It is the educators' target to improve the teaching quality and effectiveness constantly. If the teachers in college want to finish their teaching tasks and achieve teaching objects, they will face greater pressure. On the one hand, this pressure is from the subjective aspect of students; on the other hand, it is from the objective reality of society. Both cross-cutting roles and impact on teaching effectiveness constantly promote the senior teachers to reflect on their class teaching work. In order to achieve the aim that teachers teach more knowledge and some students learn some things. We can take advantage of the emerging mobile technology which is combined with the campus wireless network coverage to assist teaching by using We-chat public platform[1-4].

\section{Characteristic and Needs of Teaching Objects}

\subsection{Objects and Features}

Students who have graduated from high school and gone into the university are the main objects of teaching in higher education. This group of students has more self-control and strong analytical understanding abilities in study. In other words, most of the students choose schools and professional departments in terms of their interests; thus they have some certain interests and learning demands in related professional courses[5].

Loose learning and management atmosphere make some students reduce their demands for learning. The students don `t have pressure of the entrance after 12 years of nervous study. Students present lax status and lack motivation in study. For example, going to class on time, listening carefully, and positive statements no longer exist for them. In addition, society, age and the development of technology have negative influences on students' study. Smart phones, wireless networks, a variety of social media and lots of video information distract weak-willed students' attention. And the students' enthusiasm to participate in class is reduced greatly. Teaching effectiveness of higher teaching obviously declines and teachers are faced with students' inert learning and all kinds of new things. Teachers need to make some changes in flexible teaching methods and models.

\subsection{Teaching Object Demand}

Firstly, Students need new teaching content.

The content of the teaching materials and the development of the applications are always behind the times. To a great extent, Higher education gets rid of the secondary education test requirements and the "standard answer, which presents the open teaching features. Students need to get out of the 
teaching materials and master the knowledge. Therefore, the senior teachers are not only to stand on high by themselves in teaching, but also to encourage and guide students to contact the hot knowledge, live enterprise, and market demand to expand classroom content. So teachers and students can work together to search new knowledge by taking full advantage of a smartphone in class and after class and constantly updating their content part of textbooks and lectures and striving in the new teaching content.

Secondly, Students need innovative teaching models.

According to a large amount of news and information, science technology and the network developed modern conditions; the traditional lecture-based classroom cramming model is being challenged. First, the teachers cannot master all course-related knowledge and information outside textbooks. Second, the organization of the classroom increases the pressure. It is difficult to call students who focus on phones back to the classroom. Therefore, the focus of university teachers prepare the design of classroom model, research classroom content expansions, the grasping process, the throwing out problems, guiding and hinting and so on.

Thirdly, Students need to learn and explore cooperation.

College students have a certain self-learning ability. They can generally grasp teaching materials through lesson. But as college students, they need to have a qualitative improvement in learning ability. To gather and organize a certain amount of relevant professional knowledge outside the textbook is one of the capabilities at this stage. The teachers appropriately make some assumptions or questions. It allows curious students to finish their own tasks or they can be in cooperation with the students to answer the tasks in the class or after class. Teachers can guide students to form groups to cooperate and break down tasks.

\section{The Research of Teaching Content and Processing}

\subsection{Teaching Content Combined with Hot Issues of Era}

Combining textbook theory with practical application and comparing the old ideas with cutting-edge content is one of the hot spots which relatively work better in preparation. For higher teaching, teaching materials are only a relatively conservative and based content, teachers are not only putting the new theory and application to add to the curriculum but also selecting the teaching content which is closely in a lot of cutting-edge issues in information-rich course content, which can prompt students to master and apply this specialized knowledge.

\subsection{Teaching Content Combined with the Demands of Students}

One of the goals of senior education is to cultivate some talents who have specialized knowledge. Therefore, paying attention to the student interest is concentrating on students' responses and participating in class. A common phenomenon is that students who speak significantly decline in efficient classrooms. Many students seem to be shy and marginalized in large classes. But the fact is that some students in private are very willing to discuss topics insightfully. Teachers who use new media we-chat public platforms to assist teaching are not only resolving this conflict but also becoming better about the students' ideas and interests.

\section{The Auxiliary Teaching Modes on We-chat Public Platform}

\subsection{Features and Functions of the We-chat Public Platform}

The popularity of smart phones has accelerated the process of the mobile terminal. To a greater extent, we-chat software platform enables smartphones to overtake PCs anywhere in functionality. We-chat public platforms have obvious advantages in communication, propagation, safety, convenience and so on.

According to the survey by eMarketer[6], We-chat penetration rate increased year by year, especially in Beijing, Shanghai, Guangdong and Shenzhen, the We-chat penetration rate has reached 93\% (up to September 2015), as shown in Fig. 1. 


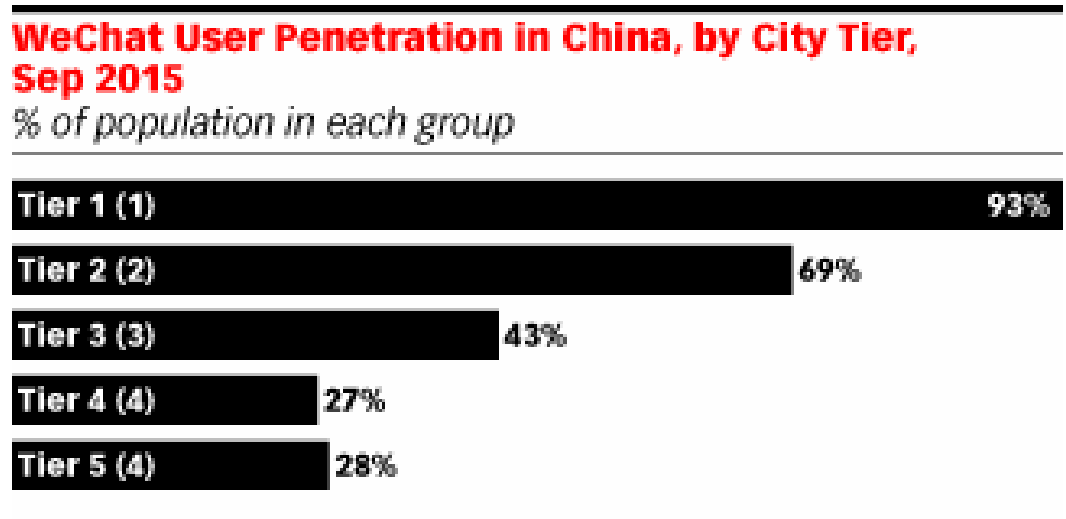

Note: also known as Weixin; (1) Beijing, Guangdong, Shanghai and

Shenzhen and municipalities; (2) provincial capital cities; (3) other mediumto large-sized cities; (4) other small-sized and county-level cities Source: Tencent, "2015 WeChat Life Report," Oct 23, 2015 200780

wwwe Marketer.com

\subsubsection{Clear Objects}

Fig. 1 Survey results of We-chat penetration by eMarketer

The object of transmission and distribution in we-chat Public platform can be clearly defined as a small part of the relevant population. Family, friends, classmates, co-workers and so on are a small diffusion. It accurately conveys the content to a specific range. We-chat public platform is used in the teaching process. You can also select students to communicate and publish content's objects.

\subsubsection{Timely Interactions}

We-chat users can publish and receive information, leave a comment view, request and obtain information at anytime and anywhere, which are we-chat platform of social and natural advantages of location[7]. We-chat software will be used in the classroom and extracurricular teaching, which is very possible and realistic. For university teachers, students in the classroom do not have to carry computers. Instead, relying on smart phones can achieve online discussions, search, receive information and facilitate other modern modes of learning.

\subsubsection{Rich Content}

Because of promotion and coverage of mobile internet technology and wireless network, smart mobile terminals browse and transfer various forms of information. We-chat user can select various forms of texts, images, voices, video sharing and disseminate information. They can share in the groups and can also reproduce in the circle of friends, forwarded, browse and comment. It is necessary to take fully advantage of this new media to assist teaching so that school can change teaching models and innovative teaching methods based on the power of teaching we-chat public platform.

\section{2 The Auxiliary Teaching Modes on We-chat Public Platform}

\section{2. 1 Creating a We-chat Public Platform for Specialized Course}

We-chat public platform's names are the same as professional courses. This is not only eye-catching but also easy to find for students. The icon is designed according to covers of textbooks or professional images.

Columns in We-chat public platform comprise three modules: teaching materials, resource sharing and professional communication. These large columns provide courseware, handouts and cutting-edge issues related to resource sharing bar. As shown in Fig. 2. 


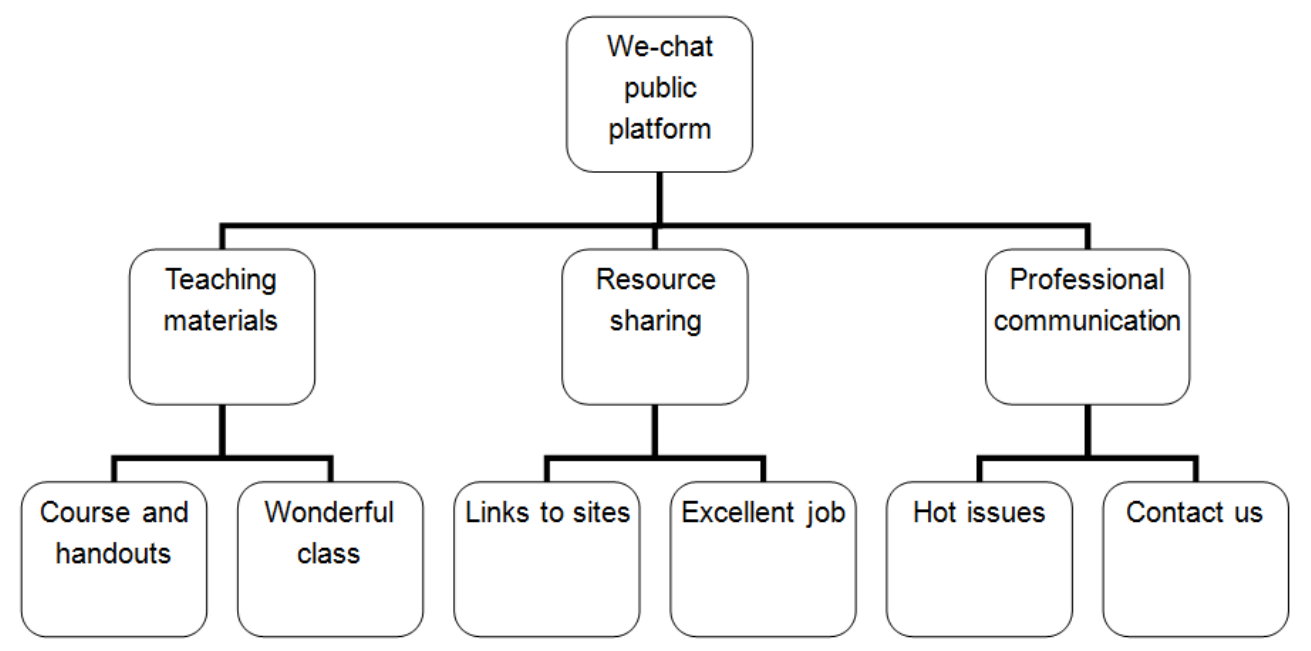

Fig. 2 Columns in the auxiliary teaching platform

\subsubsection{We-chat Public Platform Auxiliary Teaching Process}

First, the We-chat public platform should be used combine with We-chat Group. We can create a We-chat group for each lecture class and we-chat public platform can face all groups, including other related specialized students off-campus related specialized student, teachers and the public.

Second, we can take advantage of the We-chat public platform to extend from class to class and after class. Before classes, we need students to transfer data to the relevant we-chat group, facilitating students to understand the next class's teaching content.

We-chat public platform related content or video show up to guide the lesson content through a multimedia projector in the class. An excellent job can also be presented to you.

Courses are taught in the process. We-chat groups can be used to attract students' attention. For the lessons taught in the class, a We-chat group can come up with the problems. Students are given time for discussion and students can discuss the content to express their opinions in short messages. Students can answer with textbook knowledge. Students can think for themselves to put forward hypotheses and questions and you can also take advantage of free wireless campus network to search for relevant information to refine conclusions. In this way, we can attract more introverted students to practice speaking, which can make them discuss topics more enthusiastically. In this way we can stimulate students' enthusiasm for learning. Teachers can also participate in the discussion of We-chat groups and guide the group in the We-chat.

For an We-chat group, students make a wonderful hypotheses, questions and discussion and this can count as the student standing up to speak. After class, the part of content will be streamlined into questions and answers which can be published in the We-chat public platform. At the same time, the speaking of students can play a role in affirmation and encouragement.

The auxiliary teaching modes on We-chat public platform as shown in Fig. 3.

In addition, teachers can develop appropriate incentives for constructive statement, submitting high-quality jobs and professional courses. Students who provide and write relevant information for We-chat public platform are provided bonus points in the usual grades or final grade. They can encourage students to study for this course and to improve their abilities in class and after school. 


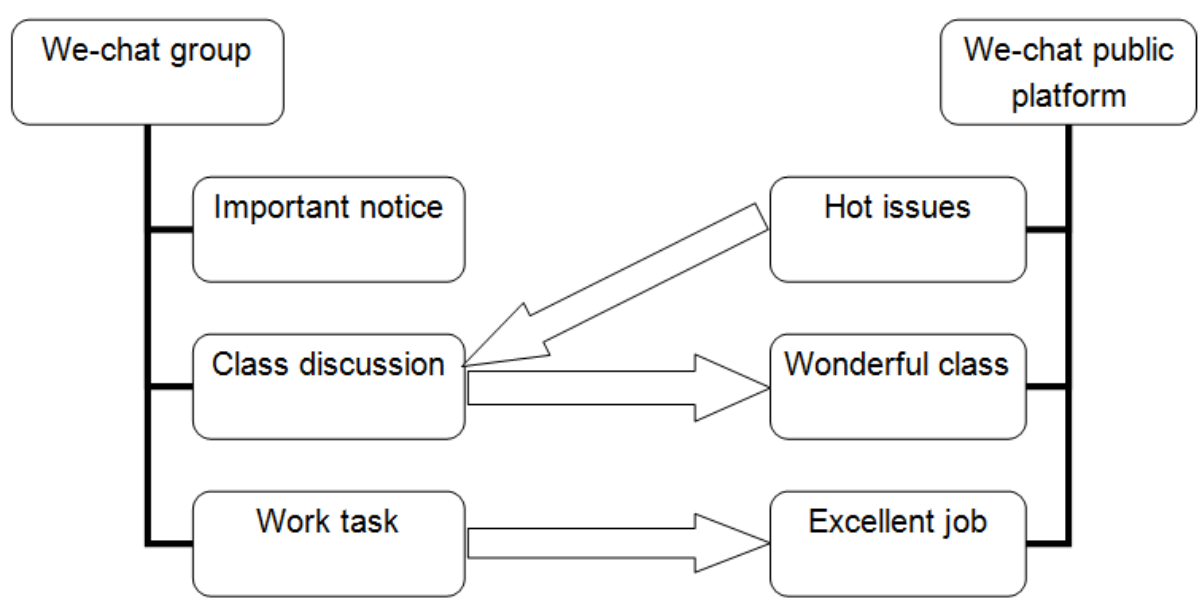

Fig. 3 The auxiliary teaching modes on We-chat public platform

\section{Conclusions}

Senior students have a strong ability to analyze problems. Due to the boring classroom atmosphere and disturbance by smartphones and social media, many students become lax in their learning attitudes, leading to a decline in classroom teaching, which make senior teachers face challenge and pressure in the teaching. This paper analyzes the features and functions of the We-chat public platform. Such studies will be able to interact in real time. It is appropriately convenient to facilitate the spread of new social media to apply to course design and pattern. By understanding the concerns of students, guiding students to participate in classroom, we assist the expansion so that we can improve teaching mode and effectiveness. Thus, the aim can be achieved that teachers teach more knowledge and students learn information.

\section{References}

[1]. Nakajima, Koichi, M. Hori, and K. Nakajima. "Mobile Internet Technology for a New Style of Learning and Teaching, " International Conference on E-Learning, E-Business, Enterprise Information Systems, \& E-Government, July 12-15, 2010, Las Vegas Nevada, Usa 2010:16-20.

[2]. Phuangthong, Dulyalak, and S. Malisawan. "A study of behavioral intention for $3 G$ mobile Internet technology: Preliminary research on mobile learning," 2010.

[3]. Zhuo, Zhang, M. Liu, and H. Zhang. "Research on the Applications of Multimedia Auxiliary Teaching System with the Computer to the Education of Clinical Medicine," Conference on Informatization in Education, Management and Business 2015:77-84.

[4]. Su, Zhihua, M. Li, and Y. Liu. "Three-Dimensional Auxiliary Teaching Course Study about MCU," International Conference on Digital Manufacturing \& Automation IEEE, 2013: 16061608.

[5]. Wu, Xiaocheng Amp, and S. Ma. "Study on Building Mode of Teaching Auxiliary Team in High Schools Based on Embedded Service," Research in Educational Development (2013).

[6]. "In China, WeChat Is Widely Used," http://www.emarketer.com/Article/China-WeChatWidely-Used/1013285.

[7]. Cong, Ying Jiu. "Research and Implementation of Auxiliary Teaching System Based on C/S Model," Applied Mechanics \& Materials 644(2014):3061-3064. 